\title{
ENERGY SAVING POTENTIAL OF NATURAL INSULATION MATERIALS IN THE BUILT ENVIRONMENT
}

\begin{tabular}{|c|c|}
\hline Hemant Kumar Singh, Aadhar Kaushik, & Kavi Prakash \\
Re & Khukla ${ }^{2}$ \\
Mechanical Engineering Department & ${ }^{2}$ Applied Mechanics Department \\
Motilal Nehru National Institute of Technology & Motilal Nehru National Institute of Technology \\
Allahabad, India & Allahabad, India \\
hemantkumarsingh83@gmail.com & \\
\hline
\end{tabular}

\begin{abstract}
-
Reduction of air conditioning loads in the built environment is one of the most important challenges in tropical countries like India, where energy shortages are common particularly during summers. Enhancing the thermal resistance of building envelope through insulation is one of the techniques commonly used. Most of the insulating materials available in the market are synthetic polymeric compounds made up of petrochemicals, e.g. Expanded polystyrene, Extruded polystyrene, Glass wool etc . Sustainability concept in the building sector has gradually led to the production of sustainable insulation products made of natural materials. This paper presents energy conservation and $\mathrm{CO}_{2}$ emission reduction potential of some building insulation products made of unconventional and natural materials, e.g. Bagasse, Sunflower leaves, Pineapple leaves, Reeds, Cardboard etc. For this purpose, energy simulations have been performed for different natural insulation materials of various thicknesses, which are proposed for a commercial bank building located at MNNIT, Allahabad, UP, India. The annual energy reduction ranges between $10 \%$ to $20 \%$ and $\mathrm{CO}_{2}$ reduction varies from 1.2 to 2.4 tonsof $\mathrm{CO}_{2}$ per year. As most of the sustainable insulation products are still at an early stage of production, their investment costs are not commercially available except for cardboard (Gutex) insulation. The simple payback period for Gutex insulation was estimated to be 5 years for $20 \mathrm{~mm}$ thickness. The use of natural materials leads to several environmental benefits. The use of agro-residues and their by products can reduce the use of polymeric insulation used in air conditioned buildings. This would help in reducing electricity demand particularly during summers, along with reduction in $\mathrm{CO}_{2}$ emissions and associated economic benefits.
\end{abstract}

\section{Introduction}

Rapid economic development, population growth and quality of life improvement in India have led to a substantial increase in energy demand outstripping the supply. Energy

supply is very capital intensive and therefore energy saving is essential for bridging the supply- demand gap. In India, four sectors that have major energy consumption are industry, transportation, building and agriculture. Building construction in India is estimated to grow at a rate of $6.6 \%$ per year in the next two decades [1].In India, primary electricity consumption in commercial sector is reported as around 8\% [2] and more than half of this usage is utilized in HVAC. Central Electrical Authority reported that country had deficit of $8.5 \%$ in energy supply and peak demand deficit was $10.3 \%$ [3].

Reduction of energy consumptions throughout the life cycle of future constructed buildings is of major concern. For the purpose thermal insulation is the most well known and, an effective energy-saving measure used on a large scale. Commonly used insulation materials for buildings are either petrochemical based or from natural sources with high energy intensive processing. Use of non-renewable materials and fossil energy consumption in the production as well as low reuse or recycling capability of synthetic polymers at the end of their lifespan causes adverse environmental impact. An analysis reports that in 2011 mineral wool (52\% of the market share) and plastics $(41 \%)$ prevailed in the world thermal insulating materials market [4]. To incorporate "sustainability" in building industry, use of natural and/or low energy recycled insulation materials is expected in near future. Such materials provide a similar or higher level of insulation and thermal comfort in buildings, as compared to synthetic insulation.

There have been a number of reported studies on the applications of various synthetic insulation materials to building envelope on cooling and heating energy uses through experimental, simulation and analytical approaches.

Satman and Yalcinkaya [5], Sisman et al.[6], Ucar and Balo [7] and Comakli and Yuksel [8] forecasted energy consumption of residential buildings, investigated Optimum Insulation Thickness (OIT) and estimated the net energy cost savings for different degree-day regions of Turkey. Shariah et al.[9] suggested that with both wall and ceiling insulated, the energy requirements could be reduced by more than $40 \%$ in Jordan. Ucar and Balo [10] also analyzed the effect of insulation thickness by considering separately heating and cooling loads. Wan et al.[11] \& Pan et al.[12] concluded that, for heating, thick insulation reduced the energy use as well as assessed the possible reduction in carbon footprint due to energy-efficient measures in China. Aktacir et al [13] investigated energy performance of the building for a cooling period under the 
Asia Pacific Journals

different thicknesses of insulation applied to the opaque external components. Energy consumption of designed air-conditioning system decreased maximum $33 \%$ due to thermal insulation. Ramesh et al. [14, 15] obtained energy saving potential of expanded polystyrene insulation on the basis of life cycle energy consumption in residential buildings in India. Unfortunately the use of natural or recycled materials for the purpose of cooling energy reduction is not particularly widespread, and has not been examined by researchers.

This study deals with energy saving potential and environmental benefits of different natural insulation materials for an office building. The annual energy savings and $\mathrm{CO}_{2}$ emissions are estimated for five different natural fiber based insulation materials for composite climate region of India. These materials are based on bagasse, reeds, sunflower, pineapple, and cardboard.

\section{Methodology}

The building opaque envelope is affected by three heat transfer mechanisms: conduction, convection and radiation. Heat transfer through conduction occurs from exterior surface to interior surface of the building, due to temperature difference as well as absorption of solar radiation by external wall surface. At the same time, convective thermal transmission occurs between ambient air and the exterior wall surface and between the interior wall surface and indoor air. Air-conditioning system used for cooling inside a building space absorbs heat produced by inmates, equipment and heat transmitted to the cooling space by the envelope due to the outside environment. Thermal insulation when properly applied retards the rate of heat flow by conduction, convection, and radiation. It retards heat flow into or out of a building due to its high thermal resistance.

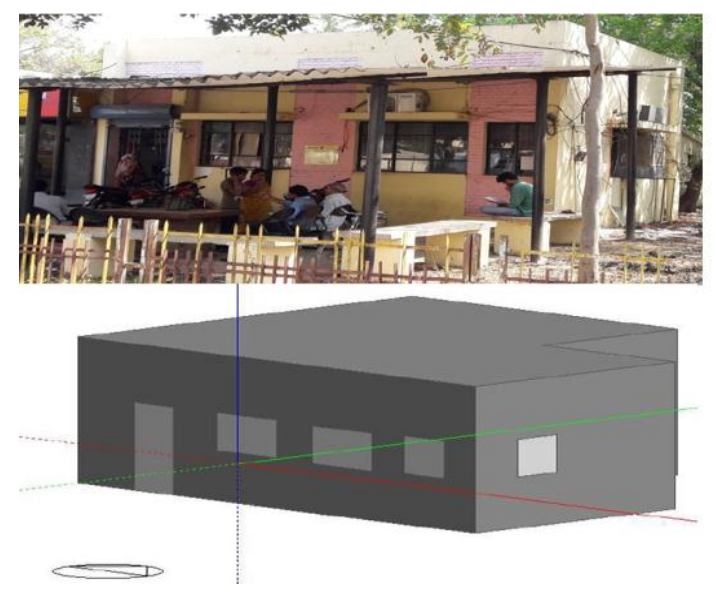

Fig. 1. Office Building and its simulated model
Table I. Specifications of commercial office building

\begin{tabular}{|c|c|c|}
\hline Parameters & Values & Material \\
\hline Building floor area & $53.4 \mathrm{~m}^{2}$ & - \\
\hline Building height & $3.5 \mathrm{~m}$ & - \\
\hline Wall thickness & $0.254 \mathrm{~m}$ & $\begin{array}{l}0.012 \mathrm{~m} \text { outer light } \\
\text { weight plaster } \\
+0.23 \mathrm{~m} \text { brick outer } \\
\text { leaf }+0.012 \mathrm{~m} \\
\text { inner light weight } \\
\text { plaster }\end{array}$ \\
\hline Roof thickness & $0.144 \mathrm{~m}$ & $\begin{array}{l}0.012 \mathrm{~m} \text { outer light } \\
\text { weight plaster } \\
+0.12 \mathrm{~m} \mathrm{RCC} 2 \% \\
\text { steel }+0.012 \mathrm{~m} \\
\text { inner light weight } \\
\text { plaster }\end{array}$ \\
\hline Window dimension & $\begin{array}{l}1.37 \mathrm{~m} \times 0.91 \mathrm{~m} \\
\text { and } 0.91 \mathrm{~m} \quad \times \\
0.91 \mathrm{~m}\end{array}$ & $\begin{array}{l}5 \mathrm{~mm} \text {, single pane, } \\
\text { clear float glass }\end{array}$ \\
\hline Door dimension & $0.95 \mathrm{~m} \mathrm{x} 2.1 \mathrm{~m}$ & $\begin{array}{l}5 \mathrm{~mm} \text {, single pane, } \\
\text { clear, soda lime } \\
\text { glass }\end{array}$ \\
\hline Total cooling load & $21 \mathrm{~kW}$ & $\begin{array}{l}1.5 \text { ton } x 4, \text { Split air } \\
\text { conditioners }\end{array}$ \\
\hline $\begin{array}{l}\text { Total lighting and fan } \\
\text { load }\end{array}$ & $17 \mathrm{~W} / \mathrm{m}^{2}$ & $\begin{array}{l}10 \text { Fluorescent } \\
\text { tubes of } 40 \mathrm{~W} \text { each } \\
+8 \text { ceiling fan of } \\
60 \mathrm{~W} \text { each }\end{array}$ \\
\hline $\begin{array}{ll}\text { Computer } & \text { and } \\
\text { peripheral load } & \end{array}$ & $20 \mathrm{~W} / \mathrm{m}^{2}$ & $\begin{array}{l}7 \text { computers of } 100 \\
\text { W each }\end{array}$ \\
\hline Occupancy density & 0.5 person $/ \mathrm{m}^{2}$ & - \\
\hline
\end{tabular}

A case study of an office building (Bank) situated at MNNIT campus, Allahabad, Uttar Pradesh, India is taken for the estimation of energy saving potential and carbon emissions mitigations for five different natural fibre insulation materials. Snap shot of the real office building as well as its simulated model is shown in fig.1. The indoor design temperature is considered as $25^{\circ} \mathrm{C}$. Details of the office building construction and electricity load are depicted in table I. A dynamic energy simulation tool DesignBuilder [16] is used for the energy simulation. It has a comprehensive user interface for EnergyPlus dynamic thermal simulation engine and generates building annual energy performance data utilizing hourly weather files of ISHRAE. The thermo-physical properties [17] of the selected five natural fiber based insulation materials are shown in table II. The cross-section of the insulated wall/roof would be as shown in figure 2 . 
Asia Pacific Journals

Table II. Thermo-physical properties of natural fiber based insulation materials [17]

\begin{tabular}{|l|l|l|l|l|l|}
\hline \multirow{2}{*}{ Properties } & \multicolumn{4}{|l|}{ Insulation materials } \\
\cline { 2 - 6 } & Bagasse & $\begin{array}{l}\text { Sun } \\
\text { flower }\end{array}$ & $\begin{array}{l}\text { Pine } \\
\text { apple }\end{array}$ & Reeds & $\begin{array}{l}\text { Card } \\
\text { board }\end{array}$ \\
\hline $\begin{array}{l}\text { Thermal Conductivity } \\
(\mathrm{W} / \mathrm{mK})\end{array}$ & 0.046 & 0.0385 & 0.035 & 0.045 & 0.037 \\
\hline Density $\left(\mathrm{kg} / \mathrm{m}^{3}\right)$ & 100 & 94 & 205 & 160 & 25 \\
\hline Specific Heat $(\mathrm{kJ} / \mathrm{kgK})$ & 1000 & 600 & 500 & 1200 & 2100 \\
\hline
\end{tabular}

Table III. Cooling load for five insulation materials

\begin{tabular}{|l|l|l|l|l|l|l|l|l|l|l|l|}
\hline \multirow{2}{*}{$\begin{array}{l}\text { Insulation } \\
\text { thickness } \\
(\mathbf{m m})\end{array}$} & \multicolumn{2}{|l|}{ Insulation materials } \\
\cline { 2 - 12 } & \multicolumn{2}{|l|}{ Bagasse } & \multicolumn{2}{l|}{ Reeds } & \multicolumn{2}{l|}{$\begin{array}{l}\text { Sunflower } \\
\text { Leaves }\end{array}$} & \multicolumn{2}{l|}{ Pineapple } & \multicolumn{2}{l|}{ Cardboard } \\
\cline { 2 - 12 } & $\mathrm{CL}^{*}$ & $\mathrm{PR}^{\#}$ & $\mathrm{CL}$ & $\mathrm{PR}$ & $\mathrm{CL}$ & $\mathrm{PR}$ & $\mathrm{CL}$ & $\mathrm{PR}$ & $\mathrm{CL}$ & $\mathrm{PR}$ \\
\hline 20 & 70.7 & 10.4 & 70.6 & 10.5 & 70.0 & 11.4 & 69.7 & 12.0 & 69.9 & 11.7 \\
\hline 40 & 68.1 & 14.7 & 67.9 & 14.9 & 67.4 & 15.8 & 67.1 & 16.4 & 67.3 & 16.0 \\
\hline 60 & 66.6 & 17.2 & 66.5 & 17.4 & 66.0 & 18.3 & 65.7 & 18.8 & 65.9 & 18.5 \\
\hline 80 & 65.6 & 18.9 & 65.5 & 19.1 & 65.1 & 19.9 & 64.8 & 20.4 & 65.0 & 20.1 \\
\hline 100 & 64.9 & 20.2 & 64.9 & 20.3 & 64.5 & 21.0 & 64.3 & 21.5 & 64.4 & 21.2 \\
\hline 120 & 64.5 & 21.1 & 64.4 & 21.2 & 64.1 & 21.8 & 63.9 & 22.3 & 64.0 & 22.0 \\
\hline
\end{tabular}

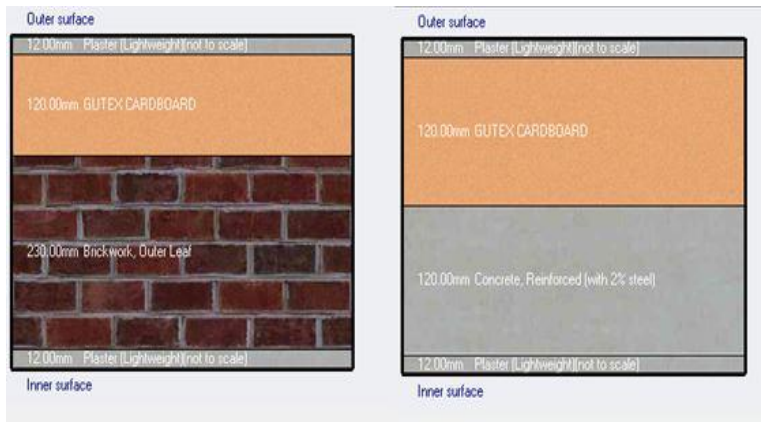

Fig. 2. Cross-section of the insulated wall/roof

\section{Results and Discussion}

Selection of these five natural insulation materials are based on their thermal diffusivity values. Thermal diffusivity for a material is the ratio of thermal conductivity and heat capacity. Thermal diffusivity measures the ability of a material to conduct thermal energy relative to its ability to store thermal energy, hence lesser the value of thermal diffusivity, better the insulation.

Total cooling load for the uninsulated office building is found to be $78.1 \mathrm{kWh} / \mathrm{m}^{2}$. The cooling load values obtained by simulating the insulated office building at MNNIT Allahabad using Design Builder software are depicted in table III. Thickness of the insulation material varies from $20 \mathrm{~mm}$ to $120 \mathrm{~mm}$ with an interval of $20 \mathrm{~mm}$. The thickness used is the standard slab thickness [18] because of the unavailability of natural insulation sheets in local market.

It is found that increasing the insulation thickness will result in a continuous reduction

in cooling load demand for the building. Increase in insulation thickness will increase the thermal resistance of building envelope and hence reduction in cooling energy demands. For all the insulation

materials examined the percentage reduction comes out to be nearly same and ranges from 10 to $22 \%$. With the increase in the insulation thickness, the cost of insulation increases but cost of energy for cooling decreases considerably. However, beyond a certain insulation thickness the energy preserving cost will not make up the integrated insulation cost and thus there must be a situation where the total expenditure on insulation and energy consumption both can be minimized. But due to unavailability of the local market cost of natural insulation, the analysis is not possible in this study. However insulation cost for Gutex cardboard insulation [18] is available as shown in table IV and based on this, the simple payback is calculated. The payback period varies from 5.3 years to 15 years. As per the literature survey the lifespan for most of the synthetic insulation materials ranges from 10 to 20 years. If we assume the same lifespan for the cardboard natural insulation, then it is seen that insulation thickness beyond $60 \mathrm{~mm}$ is not very economical. Also from percentage reduction as shown in table IV it is clear that up to 60 $\mathrm{mm}$ insulation thickness, the cooling load reduction is steep and beyond this the reduction flattens. That is employing thicker insulation is not always beneficial in terms of capital investment and cooling energy reduction both. For $60 \mathrm{~mm}$ Gutex insulation thickness the percentage reduction in building cooling load is found to be approximately $18 \%$.

Energy conservation through building insulation is an effective and environmental friendly technique, which has the potential to contribute significantly in the development of sustainable buildings. In India, around 54\% [19] of power generation is from coal based thermal power plants. The average intensity of $\mathrm{CO}_{2}$ emission from coal thermal power plants is $1.04 \mathrm{tCO}_{2} / \mathrm{MWh}$ [20]. The annual mitigation of carbon emission for a lifespan of insulation is calculated as follows:

$\mathrm{CO}_{2}$ emission mitigated (tonnes/year) $=1.04\left(\mathrm{tCO}_{2} / \mathrm{MWh}\right) \times \Delta \mathrm{E}$ (MWh/year) 
ELK

Asia Pacific Journals

Where $\Delta \mathrm{E}$ is the annual energy saving in $\mathrm{MWh} /$ year

As insulation thickness increases, $\mathrm{CO}_{2}$ emissions decrease because of the increase in energy savings. The carbon emission mitigation values obtained are depicted in table V. It is seen that the curves are steep at thinner insulation up to $60 \mathrm{~mm}$ thickness and gradually becomes asymptotic with increasing insulation thickness.

Table IV. Energy savings and payback period for cardboard insulation [18]

\begin{tabular}{|c|c|c|c|}
\hline $\begin{array}{c}\text { Insulation } \\
\text { thickness( } \\
\mathbf{m m})\end{array}$ & $\begin{array}{c}\text { Insulation } \\
\mathbf{c o s t} \\
\left(\mathbf{R s} / \mathbf{m}^{\mathbf{2}}\right)\end{array}$ & $\begin{array}{c}\text { Energy } \\
\text { savings } \\
(\mathbf{k W h} / \mathbf{y e a} \\
\mathbf{r})\end{array}$ & $\begin{array}{c}\text { Payback period } \\
\text { (years) }\end{array}$ \\
\hline 20 & 317.65 & 69.9 & 5.3 \\
\hline 40 & 565.92 & 67.3 & 7.2 \\
\hline 60 & 839.76 & 65.9 & 9.5 \\
\hline 80 & 1117.24 & 65.0 & 11.7 \\
\hline 100 & 1423.94 & 64.4 & 14.3 \\
\hline 120 & 1555.38 & 64.0 & 15.1 \\
\hline
\end{tabular}

Table V. $\mathrm{CO}_{2}$ emission mitigated in tonnes/year for various natural insulation materials

\begin{tabular}{|l|l|l|l|l|l|}
\hline \multirow{2}{*}{$\begin{array}{l}\text { Insulation } \\
\text { thickness } \\
(\mathbf{m m})\end{array}$} & \multicolumn{6}{|c|}{$\mathrm{CO}_{2}$ emission mitigated (tonnes/year) } \\
\cline { 2 - 6 } & Bagasse & Reeds & $\begin{array}{l}\text { Sun } \\
\text { flower }\end{array}$ & $\begin{array}{l}\text { Pine } \\
\text { apple }\end{array}$ & $\begin{array}{l}\text { Card } \\
\text { board }\end{array}$ \\
\hline 20 & 1.24 & 1.26 & 1.35 & 1.42 & 1.38 \\
\hline 40 & 1.69 & 1.70 & 1.79 & 1.85 & 1.82 \\
\hline 60 & 1.94 & 1.95 & 2.03 & 2.09 & 2.05 \\
\hline 80 & 2.10 & 2.12 & 2.19 & 2.23 & 2.20 \\
\hline 100 & 2.21 & 2.23 & 2.29 & 2.32 & 2.30 \\
\hline 120 & 2.29 & 2.30 & 2.36 & 2.40 & 2.38 \\
\hline
\end{tabular}

ELK Asia Pacific Journals - Special Issue

ISBN: 978-81-930411-5-4

IV. Conclusions

The present study, deals with estimation of economical insulation thickness, payback periods and carbon dioxide reduction potential calculation for natural insulation in composite climatic zone of India, with regard to cooling applications.

It is observed that with the increase in natural insulation thickness there is subsequent decrease in cooling load. The payback period shows a linear relation with insulation thickness in case of Gutex cardboard. Also thicker insulations have higher potential of $\mathrm{CO}_{2}$ emissions saving because of the increase in energy savings. Beyond a thickness of $60 \mathrm{~mm}$, the cost of installation of natural insulation will not be able to justify the reduction in cooling load;therefore a thickness of $60 \mathrm{~mm}$ will be optimum in this case. When optimum insulation thickness is applied $\mathrm{CO}_{2}$ reduction of around $1.94-2.1$ tonnes/year is observed, depending on the naturalinsulation material. Hence it is concluded that natural insulation can be an effective and sustainable substitute to synthetic insulation materials.

\section{References}

[1] McKinsey \& Company, Environmental and Energy Sustainability: An Approach for India, (McKinsey \& Company, Mumbai, India) 2009.

[2] Low Carbon Strategies for Inclusive Growth "An Interim Report" (Planning Commission, Government of India), May 2011.

[3] http://www.indiaenvironmentportal.org.in/files/file/ieb2012.pdf

[4] Building Thermal Insulation Market - By Material (Wool Insulation, Plastic Foams and Others) and Application (Roof,Wall and Floor) Global Trends and Forecasts (2011-2016);

[5] A. Satman and N. Yalcinkaya, "Heating and cooling degree-hours for Turkey," Energy, vol. 24,pp. 833-840, 1999.

[6] N. Sisman, E. Kahya, N. Aras, "Determination of optimum insulation thicknesses of the external walls and roof (ceiling) for Turkey's different degree-day regions,"EnergyPolicy, vol. 35, pp. 5151-5155, 2007.

[7] A. Ucar, F. Balo, "Effect of fuel type on the optimum thickness of selected insulation materials for the four different climatic regions of Turkey,"Appl Energy, vol. 86 pp. 730-736, 2009.

[8] K. Çomaklı, B.Yüksel, "Optimum insulation thickness of external walls for energy saving,"ApplThermEng, vol. 23,pp. 473-479, 2003.

[9] A. Ucar, F. Balo,"Determination of the energy savings and the optimum insulation thickness in the four different insulated exterior walls Renew Energy," vol. 35, pp. 88-94, 2010.

[10] Shariah, B. Tashtoush, A. Rousan,"Cooling and heating loads in residential buildings in Jordan,"Energy and buildings, vol. 26(2), pp. 137-43, 1997.

[11] K.K.W. Wan, D.H.W. Li, W Pan, J.C. Lam, "Impact of climate change on building energy use in different climate zones and mitigation and adaptation implications,"Appl Energy, vol. 86, pp. 274-282, 2012.

[12] D. Pan, M. Chan, S. Deng, Z. Lin, "The effects of external wall insulation thickness on annual cooling and heating energy uses under different climates," Appl Energy, vol. 97,pp. 313-318, 2012.

[13] M.A. Aktacir, O. Büyükalaca, T. Yılmaz,"A case study for influence of building thermal insulation on cooling load and air-conditioning system in the hot and humid regions," Appl Energy, vol. 87, pp. 599-607, 2010

[14] T. Ramesh, R.Prakash, K.K. Shukla, "Life cycle energy analysis of a residential building with different envelopes and climates in Indian context,"Appl Energy, vol. 89,pp. 193-202, 2012.

[15] T. Ramesh, R.Prakash, K.K.Shukla, "Life cycle energy analysis of buildings: An overview,"Energy and buildings, vol. 42, pp. 1592-1600, 2010 


\section{Asia Pacific Journals}

[16] DesignBuilder - Building design, simulation and visualization. (2010).www.designbuilder.co.uk.

[17] Francesco Asdrubali, Francesco D'Alessandro, Samuele Schiavoni, "A review of unconventional sustainable building insulation materials,"Sustainable Materials and Technologies, vol. 4, pp. 1-17, 2015

[18] www.indiahometips.com

[19] http://www.indiaenvironmentportal.org.in/files/file/ieb2012.pdf

[20] S. Mallah, N.K. Bansal,"Renewable energy for sustainable electrical energy system in India," Energy Policy,vol. 38 (8), pp. 3933 - 3942, 2010. 